\title{
Durability of Superheated Steam-Treated Light Red Meranti (Shorea spp.) and Kedondong (Canarium spp.) Wood against White Rot Fungus and Subterranean Termite
}

\author{
Rasdianah Dahali ${ }^{1,2}$, Seng Hua Lee ${ }^{2, *}{ }^{(}$, Zaidon Ashaari $^{1, *}$, Edi Suhaimi Bakar ${ }^{1}$, \\ Hidayah Ariffin ${ }^{2,3}{ }^{-0}$, Pui San Khoo ${ }^{2}$, Paiman Bawon ${ }^{1, *}$ and Qamariah Norhidayah Salleh ${ }^{1}$ \\ 1 Faculty of Forestry, Universiti Putra Malaysia, Serdang 43400 UPM, Selangor, Malaysia; \\ rasdianahdahali@gmail.com (R.D.); edisuhaimi@upm.edu.my (E.S.B.); qamasalleh88@gmail.com (Q.N.S.) \\ 2 Institute of Tropical Forestry and Forest Products, Universiti Putra Malaysia, Serdang 43400 UPM, Selangor, \\ Malaysia; hidayah@upm.edu.my (H.A.); sansan_0928@hotmail.com (P.S.K.) \\ 3 Biomass Technology Centre, Faculty of Biotechnology and Biomolecular Sciences, Universiti Putra Malaysia, \\ Serdang 43400 UPM, Selangor, Malaysia \\ * Correspondence: lee_seng@upm.edu.my (S.H.L.); zaidon@upm.edu.my (Z.A.); paiman@upm.edu.my (P.B.)
}

Received: 12 March 2020; Accepted: 8 April 2020; Published: 29 May 2020

check for updates

\begin{abstract}
In this study, the effect of superheated steam (SHS) treatment on the changes of the chemical composition and biological properties of two tropical hardwoods was investigated. SHS was carried out on light red meranti (Shorea spp.) and kedondong (Canarium spp.) wood with dimensions of $410 \times$ $25 \times 25 \mathrm{~mm}$, using superheated steam as the heating medium. Wood samples were heat-treated at nine treatment levels, ranging from 172 to $228^{\circ} \mathrm{C}$ and 95 to $265 \mathrm{~min}$, respectively. The chemical constituents and resistance against white rot fungus (Pycnoporus sanguineus) and subterranean termite (Coptotermus curvignathus) of the treated wood were evaluated. A significant reduction in holocellulose content and increment in lignin was observed after SHS treatment. Consequently, the resistance against white rot fungus and termites improved. The biological durability improved with an increasing treatment temperature and time. A regression analysis revealed that the reduced equilibrium moisture content imparted superior biological resistance to the treated wood. Weight loss caused by the thermal degradation also served as a good indicator for fungal decay, as the loss of weight was directly proportional to the improvement in fungal resistance. However, this did not apply to termite resistance, as a very weak relationship was found between the two variables.
\end{abstract}

Keywords: superheated steam treatment; chemical constituents; Pycnoporus sanguineus; Coptotermes curvignathus; mass loss

\section{Introduction}

Sufficient water within cell walls or wet wood and the contact of the wood with soil provides a favorable condition for fungi and termites in degrading wood in use [1]. As a result of the degradation caused by these wood destroying organisms, millions of USD are spent each year to replace the decayed wood products. This results in economic losses, with far-reaching impact on the increasing demand for timber. Termites have long been known to cause serious structural damages to buildings. An estimation of 40 billion USD economic loss is reported worldwide annually as a result of termite attacks on building structures [2]. It is estimated that, in the year of 2010, the economic losses caused by subterranean termites was approximately 32 billion USD for preventive measures and damage repairs [3]. According to Ngee et al. [4], the total cost spent in Malaysia for termite prevention control 
is about 10 to 12 million USD annually and a high percentage of this loss is incurred by consumers. Surprisingly, the total of the repair costs is estimated to be 3 to 4 times higher than the cost for termite control [4]. On the other hand, fungi were found to be detrimental to building structures, as decayed wood exhibits serious mass and strength loss [5]. Morrell [6] estimates that $10 \%$ of the lumber harvested every year is used to replace timber decayed by fungi. It has been reported that the financial losses in the USA alone due to wood decay are amounted to around 300 million USD annually, not including the cost of protective measures.

Shorea spp., or light red meranti, is a light tropical hardwood that can be easily found in the Malaysian forest, along with kedondong (Canarium spp.). Both species are favored by the timber-based industries in Malaysia for sawn timber and plywood production. The timbers of both species are very popular as general utility timbers. Large-scale plantation forests of Shorea smithiana-a member of the light red meranti group of timbers-have been established, owing to its versatility in wood-based industries [7]. Meanwhile, Canarium spp. is also well-distributed in tropical and sub-tropical forests around the world, from Nigeria to Australia and Pacific tropical islands, where around 100 species of Canarium spp. were recorded [8]. Nevertheless, upon exposure to the weather or contact with the ground, both species are classified as non-durable. The standard graveyard tests revealed that untreated kedondong wood has an average service life of 1.2 years, while light red meranti has less than 2 years [9]. Meanwhile, balau (Shorea maxwelliana) was reported to have a service life of 15.8 years, making it one of the most durable timbers tested in Peninsular Malaysia [9]. In addition, both light red meranti and kedondong wood are very susceptible to the attack of drywood termites. Therefore, both woods must be treated to attain an acceptable level of biological durability. However, both species have very low treatability and are resistant to preservative impregnation treatment, hindering the efforts to improve their biological resistance.

The application of toxic chemicals for wood protection, constrained by the poor resistance of tropical hardwoods towards fungal and termite attacks, have attracted considerable attention to those who are keen advocates of environmental conservation [10]. Therefore, this opens the possibility of utilizing non-toxic methods in the treatment of wood. Thermal treatment is one green treatment that focuses on the conversion of wood from its inherent hydrophilic nature to hydrophobic via the degradation of the hydroxyl group by high temperatures [11]. The reduction in equilibrium moisture content (EMC) and improvement in dimensional stability resulting from thermal treatment is common for thermally-treated wood [12,13]. Constrained by the low treatability of light red meranti and kedondong wood, thermal treatment is undoubtedly a better treatment method designated for the mentioned tropical hardwood.

Treatment using heat at temperatures over $150^{\circ} \mathrm{C}$ is a promising method to improve the biological durability of wood materials [14]. Chaouch et al. [15] heat treated beech, poplar, ash, pine, and silver fir wood under nitrogen conditions and reported that the mass loss caused by brown rot fungus decreased progressively. Radiata pine was thermally modified with linseed oil, and its decay resistance against brown rot fungus was improved [16]. On the other hand, Norway spruce, silver fir, European ash, and European beech were heat-treated by Gao et al. [17] and the results revealed significant improvement in the resistance against both white rot and brown rot fungi observed at treatment temperatures between 200-220 ${ }^{\circ} \mathrm{C}$. In addition, the effects of heat treatment are species dependent, as softwoods displayed inferior decay resistance compared to that of the hardwoods [18].

In terms of termite resistance, contradictory results are often narrated by a number of researchers. A considerable enhancement against termite attacks was observed in thermally-modified Southern silky oak [19]. Similar findings were also published by Lyon et al. [20] and Manola and Garcia [21] in oil heat-treated beech and bamboo. Nevertheless, severe attacks in heat-treated wood by termites compared to untreated wood were disclosed by some studies [22-24]. Apart from termite resistance, thermal treatment was also found to confer better mold resistance to the wood [25]. Ahmed et al. [26] thermally-modified Scots pine sapwood under saturated steam conditions and reported that the treated wood exhibited significant improvement in durability against mold. Superheat steam (SHS) treatment 
has also been employed to reduce the hygroscopicity of wood [27]. The advantages of SHS over other treatments is that it is processed in an air-free environment that enhances the quality of the product, improves energy efficiency, produces higher drying rates, and reduces the impact on the environment when the condensate is reused [28]. Although SHS requires a longer treatment time compared to steam explosion and high-pressure steam treatment, the process can be considered safe because it has a low risk of fire [29]. In addition, SHS treatment is a cost-effective method for large-scale purposes [30].

Although thermal treatment studies on temperate wood species have been extensively reported, there are relatively scarce reports or literature on the influence of thermal treatment on the biological durability of tropical hardwood. The aims of this study were to determine the effectiveness of superheated steam treatment on the improvement of resistance against white rot fungus (Pycnoporus sanguineus) and termites (Coptotermus curvignathus) for both of the wood species examined in the present study. Light red meranti (LRM) and kedondong (KDD) were selected as the treated materials, as both species are low density hardwoods that are non-durable against fungal decay and termite attacks. In addition, the woods are dimensionally unstable and difficult to be treated with preservatives. Resin and tyloses exist in the wood of this species, making them highly resistant to preservative treatment, since they block the penetration of solution into the wood. Thus, the SHS treatment could be a potential thermal treatment to enhance the biological and physical properties of these woods. It is hoped that, with improved durability and physical properties, these two species could help in ensuring the sustainability of wood-based industries, where the supply of quality tropical hardwood timber is running low.

\section{Materials and Methods}

\subsection{Raw Material Preparation}

The material used in this study were light red meranti (Shorea spp.) and kedondong (Canarium spp.) wood extracted from a matured tree felled in a local natural forest. The logs were processed at a local sawmill located in Dengkil, Selangor. Only the bottom parts of $4 \mathrm{~m}$ length were selected and they were flat sawn into $5 \mathrm{~cm}$ thick samples. This was to reduce the density variations along the stem of the woods. The samples were air-dried to approximately $12 \%-15 \%$ moisture content. After drying, end-matched samples that were free from defects were cut into the nominal dimension of $410 \mathrm{~mm}$ long $\times 25 \mathrm{~mm}$ wide $\times 25 \mathrm{~mm}$ thick. Then, the samples were conditioned at a temperature of $20 \pm 2{ }^{\circ} \mathrm{C}$ and a humidity of $65 \pm 2 \%$ until a constant weight was achieved. At this condition, the equilibrium moisture content (EMC) of the woods was approximately $12 \%$ moisture content (MC). The samples were ranked according to density and were numbered from highest to lowest density. They were then divided into 10 groups (nine groups for treated groups and one group for the untreated group), where each group should have consisted of an equal number of samples with the same density range to minimize error. Each of the treatment combination groups consisted of five replicates.

\subsection{Optimizing of SHS Treatment Variables}

The heat treatment of wood is commonly carried using temperatures ranging between $160^{\circ} \mathrm{C}$ and $260^{\circ} \mathrm{C}$, with most studies using temperatures below $220^{\circ} \mathrm{C}$. For instance, in their study on oil heat treatment with rubberwood, Umar et al. [31] employed temperatures in the range of 172 to $228^{\circ} \mathrm{C}$ and times of 95 to $265 \mathrm{~min}$, respectively. Therefore, these treatment temperatures and times were used as the benchmark for the treatment parameters. These parameters were specifically designed using Design Expert Software version 9 (State Ease, 2014) to obtain the independent treatment variables. Central composite design (CCD) was chosen in this study to investigate the combined effect of these two independent variables. Heat treatment was designed according to 9 runs/treatment of CCD, with the temperature ranging from 172 to $228^{\circ} \mathrm{C}$ and the duration time ranging from 95 to $265 \mathrm{~min}$ (Table 1), using the response surface methodology (RSM) approach. Table 1 shows the experimental conditions of the superheated steam treatment used in this study. 
Table 1. Experimental conditions of superheated steam treatment.

\begin{tabular}{ccc}
\hline Treatment & Temperature $\left({ }^{\circ} \mathbf{C}\right)$ & Time $(\mathbf{m i n})$ \\
\hline T1 & 172 & 180 \\
T2 & 180 & 120 \\
T3 & 180 & 240 \\
T4 & 200 & 95 \\
T5 & 200 & 180 \\
T6 & 200 & 265 \\
T7 & 220 & 120 \\
T8 & 220 & 240 \\
T9 & 228 & 180 \\
\hline
\end{tabular}

The SHS treatment was conducted in the laboratory of the Biomass Technology Centre at the Faculty of Biotechnology and Biomolecular Sciences, Universiti Putra Malaysia (UPM). The wood specimens were treated using a laboratory-scale SHS oven (QF-5200C, Naomoto Corporation, Osaka, Japan) at the designated treatment temperature and duration time, as listed in Table 1. First, the SHS oven was preheated until the desired treatment temperature was achieved and stable, before the samples were placed into the oven. The SHS oven consisted of two separate parts-i.e., a stainless-steel heating oven and a boiler. The boiler operated at the power of $6.3 \mathrm{~kW}$, with a steam pressure of $0.1 \mathrm{MPa}$. The steam was produced from the boiler at $100^{\circ} \mathrm{C}$, and this steam was further heated by a heater that converted it into transparent gas known as a SHS. This SHS was injected into the samples placed in the heating oven. An electric heater, rated at $5.5 \mathrm{~kW}$, was installed in the heating oven to maintain the steam temperature under superheated conditions. Steam was used to prevent the samples from undesired oxidation. The schematic view of the SHS oven treatment is illustrated in Figure 1.

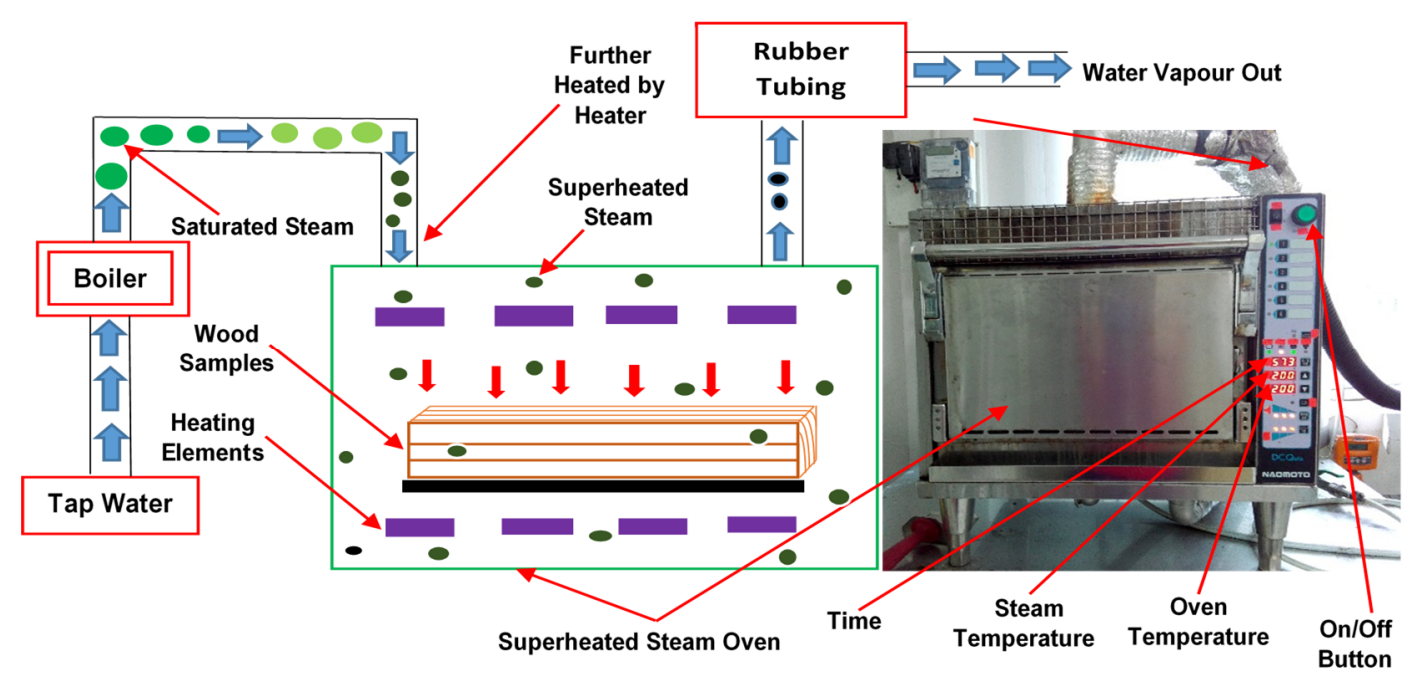

Figure 1. Schematic view of a superheated steam (SHS) oven [27].

\subsection{Determination of Weight Loss and Equilibrium Moisture (EMC) after SHS Treatment}

The weight loss and equilibrium moisture (EMC) of the wood samples, after being treated with SHS, were conducted according to Rasdianah et al. [27]. The wood samples were conditioned after SHS treatment until constant weights were attained. The weights of the samples were then weighed and recorded. The weight loss due to SHS treatment, expressed in percentage, was calculated based on the difference in weight of the wood samples before and after treatment. For EMC determination, blocks with dimensions of $25 \mathrm{~mm} \times 25 \mathrm{~mm} \times 25 \mathrm{~mm}$ were used. The wood blocks were dried in an oven set at $103 \pm 2{ }^{\circ} \mathrm{C}$ until constant weights were achieved. The weight of the oven-dried samples were then recorded. Next, the wood blocks were placed into a desiccator at an ambient temperature. 
A petri dish filled with water was put into the desiccator to create a relative humidity of $98 \pm 2 \%$. The weights of the conditioned wood blocks were reweighed until they reached a constant weight. The EMC of the wood blocks was determined as follows:

$$
\operatorname{EMC}(\%)=100\left(\mathrm{~W}_{2}-\mathrm{W}_{1}\right) / \mathrm{W}_{1}
$$

where $W_{1}$ is the oven-dried (OD) weight of the samples (g) and $W_{2}$ is the constant weight of the samples after reconditioning (g). Five replicates were tested for every treatment level.

\subsection{Evaluation of Chemical Properties}

After conditioning, small splints ( 1 to $2 \mathrm{~cm}$ long) were taken from each treated and untreated sample to evaluate the chemical properties. The splints were ground using a Wiley mill to produce particles. The particles were then screened using a 40 to 60 mesh $(0.4$ to $0.6 \mathrm{~mm})$ sieve according to the Technical Association of the Pulp and Paper Industry (TAPPI ) standard method T $257 \mathrm{~cm}-02$ [32] to obtain homogeneous particle sizes. These particles were then used for wet chemical analysis. The determination of extractives, holocellulose, alpha-cellulose, and lignin contents of the samples were determined following the protocol specified in TAPPI standards and Wise's method-namely, T204 cm-97 [33], Wise's sodium chlorite method, T212 om-93 [34], and T222 om-02 [35], respectively. The hemicelluloses were determined by subtracting the alpha-cellulose from the holocellulose contents. All percentages of chemical constituents for the superheated steam-treated and control samples were analyzed in triplicate.

\subsection{Evaluation of Biological Properties}

\subsubsection{Decay Resistance}

For decay resistance, the superheated steam-treated and control samples were assessed according to ASTM standard D1413-76 [36], using white rot fungus (Pycnoporus sanguineus). White rot fungi are the only microorganisms known to efficiently degrade all the components of wood, including lignin [37]. The Malaysian Timber Council uses white rot fungi as a guide to measure the durability of Malaysian timbers, as hardwoods are generally more susceptible to white rot than brown rot fungi [38]. In this study, P. sanguineus was selected as a test fungus because it is a common basidiomycete that is easily found in tropical countries. It causes considerable damage, even among supposedly durable timber [39]. P. sanguineus was collected from an infested pine stand from a pine plantation in the Institute of Bioscience, Universiti Putra Malaysia, and was cultured in the Wood Deterioration and Treatment Laboratory at the Faculty of Forestry, Universiti Putra Malaysia. For each group, five replicates of test blocks ( $25 \mathrm{~mm}$ long $\times 25 \mathrm{~mm}$ wide $\times 10 \mathrm{~mm}$ thick) of untreated and treated wood were prepared. Each culture bottle was filled with $150 \mathrm{~g}$ sieved soil and $70 \mathrm{~mL}$ distilled water. For fungus inoculation, feeder strips of rubberwood ( $35 \mathrm{~mm}$ long $\times 28 \mathrm{~mm}$ wide $\times 3 \mathrm{~mm}$ thick) were placed on top of the soil in each culture bottle. Then, the bottles were steam-sterilized at $121{ }^{\circ} \mathrm{C}$ for 30 min and were cooled at room temperature. After cooling, P. sanguineus was placed at the corner of the feeder strip and the bottles were incubated at a temperature between 25 to $27^{\circ} \mathrm{C}$ for approximately 3 weeks. When the feeder strips were covered by mycelium, the test blocks were placed on top of the mycelium-covered feeder strips. The bottles containing the test blocks were incubated for 12 weeks. At the end of the incubation period, the test blocks were taken out from the bottles and all the mycelium on the test block surfaces were removed. The test blocks were then oven- dried until constant weights were attained. Each block was weighed and the percentage of weight loss for the test block was calculated using Equation (1):

$$
\mathrm{WL}(\%)=100\left(\frac{\mathrm{W} i-\mathrm{W} f}{\mathrm{~W} i}\right)
$$


where $\mathrm{W} i$ is the initial weight of the test block before exposure to fungi $(\mathrm{g})$, and $\mathrm{W} f$ is the final weight of the test block after exposure to fungi (g).

\subsubsection{Termite Resistance}

Termite resistance tests were conducted in accordance with ASTM D 3345-08 [40]. Test blocks of $25 \mathrm{~mm}$ long $\times 25 \mathrm{~mm}$ wide $\times 7 \mathrm{~mm}$ thick were prepared from the treated and untreated wood samples. Subterranean termite, Coptotermus curvignathus, were collected from an infested pine plantation located near the Institute of Bioscience, Universiti Putra Malaysia. The subterranean termites (C. curvignathus) were used in this test because the Coptotermes species is the most destructive and most responsible for the great economic loss caused by the total infestation of buildings and wooden structures in Malaysia [39]. Pine wood blocks were used as bait to trap the termites, and the trapped termites were then separated from the debris. The culture bottles were filled with $200 \mathrm{~g}$ of sterilized sand, and $30 \mathrm{~mL}$ distilled water were added before the test blocks were put into the bottles. Approximately $1 \pm 0.05 \mathrm{~g}$ of C. curvignathus, consisting of $90 \%$ workers and $10 \%$ soldiers, were weighed and introduced into each bottle. The cultured bottles were then covered with black plastic and left at room temperature for 4 weeks. After 4 weeks, the test blocks were removed from the cultured bottles and oven-dried in an oven until a constant weight was attained. Each test block was examined based on the weight loss percentage, using Equation (2).

$$
\mathrm{WL}(\%)=100\left(\frac{\mathrm{W} i-\mathrm{W} f}{\mathrm{~W} i}\right)
$$

where $\mathrm{W} i$ is the initial weight of the test block before exposure to termites $(\mathrm{g})$ and $\mathrm{W} f$ is the weight of the test block after exposure to termites (g).

\subsection{Statistical Analysis}

The data were analyzed using analysis of variance (ANOVA) to assess the effects of treatment on the chemical and biological properties of treated wood. Duncan's multiple range test, at $p \leq$ 0.05 , was employed to further determine the significant level between average values for every treatment variable.

\section{Results and Discussion}

\subsection{Weight Loss and EMC after SHS Treatment}

The weight loss and EMC data were adapted from our previous paper [27]. The weight loss as a result of SHS treatment for both LRM and KDD is listed in Table 2. The weight loss after SHS treatment ranged from $7.76 \%$ to $11.48 \%$ for LRM. On the other hand, the weight losses ranging from $8.19 \%$ to $18.55 \%$ were recorded for KDD after being subjected to SHS treatment. Weight loss was found to increase along with the increase of treatment severity. The weight loss of wood as a result of heat treatment is a vital indicator to determine the quality of the treatment employed [41]. The EMC of the treated and untreated wood samples are also listed in Table 2. The EMC of the wood decreased along with the increasing treatment severity. 
Table 2. Weight loss and equilibrium moisture content (EMC) of untreated and treated light red meranti (LRM) and kedondong (KDD).

\begin{tabular}{ccccc}
\hline \multirow{2}{*}{ Treatment } & \multicolumn{2}{c}{ Weight Loss (\%) } & \multicolumn{2}{c}{ EMC (\%) } \\
\cline { 2 - 5 } & LRM & KDD & LRM & KDD \\
\hline Untreated & - & - & $12.81^{\mathrm{a}}$ & $11.66^{\mathrm{a}}$ \\
T1 & $8.18^{\mathrm{d}}$ & $8.19^{\mathrm{d}}$ & $8.05^{\mathrm{b}}$ & $6.81^{\mathrm{c}}$ \\
T2 & $8.07^{\mathrm{d}}$ & $9.30^{\mathrm{d}}$ & $7.87^{\mathrm{b}}$ & $8.26^{\mathrm{b}}$ \\
T3 & $8.71^{\mathrm{cd}}$ & $10.37^{\mathrm{d}}$ & $7.56^{\mathrm{c}}$ & $7.80^{\mathrm{b}}$ \\
T4 & $8.06^{\mathrm{d}}$ & $9.58^{\mathrm{d}}$ & $7.43^{\mathrm{bcd}}$ & $6.70^{\mathrm{c}}$ \\
T5 & $7.76^{\mathrm{d}}$ & $12.67^{\mathrm{c}}$ & $6.97 \mathrm{~b}^{\mathrm{c}}$ & $6.57^{\mathrm{c}}$ \\
T6 & $9.41^{\mathrm{bc}}$ & $12.88^{\mathrm{bc}}$ & $6.80^{\mathrm{d}}$ & $6.34^{\mathrm{c}}$ \\
T7 & $10.09^{\mathrm{b}}$ & $15.05^{\mathrm{b}}$ & $5.77^{\mathrm{c}}$ & $5.53^{\mathrm{d}}$ \\
T8 & $11.47^{\mathrm{a}}$ & $17.28^{\mathrm{a}}$ & $5.51^{\mathrm{e}}$ & $4.77^{\mathrm{d}}$ \\
T9 & $11.48^{\mathrm{a}}$ & $18.55^{\mathrm{b}}$ & $4.65^{\mathrm{f}}$ & $4.98^{\mathrm{d}}$ \\
\hline
\end{tabular}

Note: Means followed by the same letters ${ }^{\mathrm{a}, \mathrm{b}, \mathrm{c}, \mathrm{d}, \mathrm{e}}$ within the same properties column are not significantly different at $p \leq 0.05$. Source: Adapted from previous study [27].

\subsection{Wet chemical Analysis}

Table 3 presents the changes of the chemical composition of light red meranti and kedondong specimens after SHS treatment at different treatment parameters. The cellulose and hemicellulose of the untreated light red meranti (LRM) were $42.51 \%$ and $32.11 \%$, respectively, while untreated kedondong (KDD) were $44.33 \%$ and $32.09 \%$, respectively.

Table 3. Mean chemical composition of light red meranti and kedondong after SHS treatment.

\begin{tabular}{ccccc}
\hline \multirow{2}{*}{ Treatment } & \multicolumn{4}{c}{ Chemical Composition (\%) } \\
\cline { 2 - 4 } & Holo-Cellulose & Alpha Cellulose & Hemi-Cellulose & Lignin \\
\hline Untreated & $74.62 \pm 0.28^{\mathrm{c}}$ & Light red meranti \\
T1 & $73.53 \pm 1.12^{\mathrm{c}}$ & $41.62 \pm 1.64^{\mathrm{cd}}$ & $31.91 \pm 2.19^{\mathrm{a}}$ & $23.71 \pm 1.81^{\mathrm{a}}$ \\
T2 & $72.87 \pm 1.01^{\mathrm{c}}$ & $41.21 \pm 0.96^{\mathrm{cd}}$ & $31.66 \pm 0.16^{\mathrm{a}}$ & $25.25 \pm 1.98^{\mathrm{a}}$ \\
T3 & $67.01 \pm 2.41^{\mathrm{b}}$ & $40.14 \pm 1.15^{\mathrm{bcd}}$ & $26.87 \pm 1.26^{\mathrm{a}}$ & $31.15 \pm 1.03^{\mathrm{b}}$ \\
T4 & $65.86 \pm 2.50^{\mathrm{ab}}$ & $39.24 \pm 1.34^{\mathrm{abcd}}$ & $26.62 \pm 3.38^{\mathrm{a}}$ & $31.20 \pm 1.17^{\mathrm{b}}$ \\
T5 & $65.93 \pm 1.28^{\mathrm{ab}}$ & $38.43 \pm 0.77^{\mathrm{abc}}$ & $27.50 \pm 2.04^{\mathrm{a}}$ & $32.27 \pm 1.34^{\mathrm{bc}}$ \\
T6 & $66.15 \pm 3.07^{\mathrm{ab}}$ & $36.94 \pm 2.46^{\mathrm{ab}}$ & $29.21 \pm 4.85^{\mathrm{a}}$ & $30.44 \pm 2.35^{\mathrm{b}}$ \\
T7 & $65.02 \pm 5.15^{\mathrm{ab}}$ & $36.41 \pm 3.52^{\mathrm{a}}$ & $28.61 \pm 8.02^{\mathrm{a}}$ & $31.05 \pm 1.02^{\mathrm{b}}$ \\
T8 & $62.27 \pm 3.91^{\mathrm{ab}}$ & $35.76 \pm 2.02^{\mathrm{a}}$ & $26.51 \pm 2.91^{\mathrm{a}}$ & $34.24 \pm 1.05^{\mathrm{c}}$ \\
T9 & $61.91 \pm 1.26^{\mathrm{a}}$ & $36.58 \pm 2.07^{\mathrm{a}}$ & $25.33 \pm 1.31^{\mathrm{a}}$ & $34.44 \pm 1.86^{\mathrm{c}}$ \\
& & & \\
Untreated & $76.42 \pm 2.18^{\mathrm{d}}$ & $44.33 \pm 2.0^{\mathrm{d}}$ & $32.09 \pm 0.36^{\mathrm{e}}$ & $21.94 \pm 1.96^{\mathrm{a}}$ \\
T1 & $71.89 \pm 1.73^{\mathrm{c}}$ & $43.21 \pm 1.3^{\mathrm{cd}}$ & $28.68 \pm 0.7^{\mathrm{de}}$ & $27.98 \pm 1.88^{\mathrm{b}}$ \\
T2 & $70.40 \pm 3.99^{\mathrm{bc}}$ & $42.71 \pm 2.16^{\mathrm{bcd}}$ & $27.69 \pm 2.87^{\mathrm{cd}}$ & $27.68 \pm 1.97^{\mathrm{b}}$ \\
T3 & $66.03 \pm 1.78^{\mathrm{ab}}$ & $41.86 \pm 1.97^{\mathrm{abcd}}$ & $24.17 \pm 2.1^{\mathrm{abc}}$ & $30.88 \pm 1.98^{\mathrm{bc}}$ \\
T4 & $65.91 \pm 2.30^{\mathrm{ab}}$ & $40.92 \pm 2.83^{\mathrm{abcd}}$ & $24.99 \pm 0.98^{\mathrm{abcd}}$ & $30.66 \pm 2.02^{\mathrm{bc}}$ \\
T5 & $62.43 \pm 2.55^{\mathrm{a}}$ & $39.31 \pm 2.52^{\mathrm{abc}}$ & $23.12 \pm 1.98^{\mathrm{ab}}$ & $33.41 \pm 1.56^{\mathrm{c}}$ \\
T6 & $61.24 \pm 1.15^{\mathrm{a}}$ & $39.63 \pm 1.11^{\mathrm{abc}}$ & $21.61 \pm 2.22^{\mathrm{a}}$ & $33.53 \pm 2.48^{\mathrm{c}}$ \\
T7 & $64.48 \pm 2.53^{\mathrm{a}}$ & $38.91 \pm 0.79^{\mathrm{ab}}$ & $25.57 \pm 1.77^{\mathrm{abcd}}$ & $30.93 \pm 1.82^{\mathrm{bc}}$ \\
T8 & $64.33 \pm 2.94^{\mathrm{a}}$ & $38.45 \pm 3.56^{\mathrm{a}}$ & $25.88 \pm 4.34^{\mathrm{bcd}}$ & $30.91 \pm 3.17^{\mathrm{bc}}$ \\
T9 & $63.29 \pm 2.87^{\mathrm{a}}$ & $37.73 \pm 1.82^{\mathrm{a}}$ & $25.56 \pm 1.89^{\mathrm{abcd}}$ & $32.10 \pm 0.96^{\mathrm{c}}$ \\
\hline
\end{tabular}

Note: Means followed by the same letters $\mathrm{a}, \mathrm{b}, \mathrm{c}, \mathrm{d}, \mathrm{e}$ are not significantly different at $p \leq 0.05$.

It can be observed from Table 3 that both polysaccharides decreased after superheat steam (SHS) treatment, and the decrement increased along with the increasing treatment severity. The decrement of hemicellulose content was found to be higher than cellulose content after SHS treatment. The highest 
reduction of hemicellulose content for LRM was recorded when the samples were exposed to a treatment temperature of $228{ }^{\circ} \mathrm{C}$ for $180 \mathrm{~min}$ (T9), which was $25.33 \%$. Meanwhile, for the KDD sample, the hemicellulose content was highly reduced from $32.09 \%$ to $21.61 \%$ when the samples were exposed to $200{ }^{\circ} \mathrm{C}$ for $265 \mathrm{~min}$ (T5). On the other hand, the treatment at $220{ }^{\circ} \mathrm{C}$ for $240 \mathrm{~min}$ (T8) and $228^{\circ} \mathrm{C}$ for $180 \mathrm{~min}$ (T9) were found to lead to the lowest cellulose contents for SHS-treated LRM and KDD, respectively. Correspondingly, the lignin content of the treated samples increased due to the reduction of holocellulose. The lignin content for both specimens increased from $23.71 \%$ to $34.44 \%$ and $27.68 \%$ to $33.53 \%$, respectively, for LRM and KDD.

Hemicellulose was the most sensitive component and degraded faster during SHS treatment [42,43]. The degradation of hemicellulose was due to the amorphous structure and the lower molecular weights compared to cellulose. In comparison to hemicellulose, cellulose is less affected by SHS treatment, owing to its crystal structure that offers great stability to the cellulose chains. This structure protects them against acid attack during hydrolysis and the accessibility of the glucosidic bonds is very limited [44]. Zaman et al. [42] stated in their research that the lignin content increased gradually, with a simultaneous decrease in hemicellulose and cellulose during heat treatment. Tjeerdsma et al. [45] and Kishimoto et al. [46] reported that the condensation reactions of lignin may result in higher lignin content.

\subsection{Fungal Decay}

The visual appearance for the treated and untreated samples of LRM and KDG after 12-weeks exposure to white rot fungi (P. sanguineus) is shown in Figure 2. From the observation, both species exhibited a similar decay pattern, where the untreated specimen were severely attacked by the $P$. sanguineus. The fungus colonized the untreated sample (UNT) and the whole specimen was fully covered by the mycelium. For the SHS-treated samples, less mycelium was seen covering the samples. For those samples that were treated at the highest temperature (T9), only a little spot of mycelium was observed on the surface of the sample.
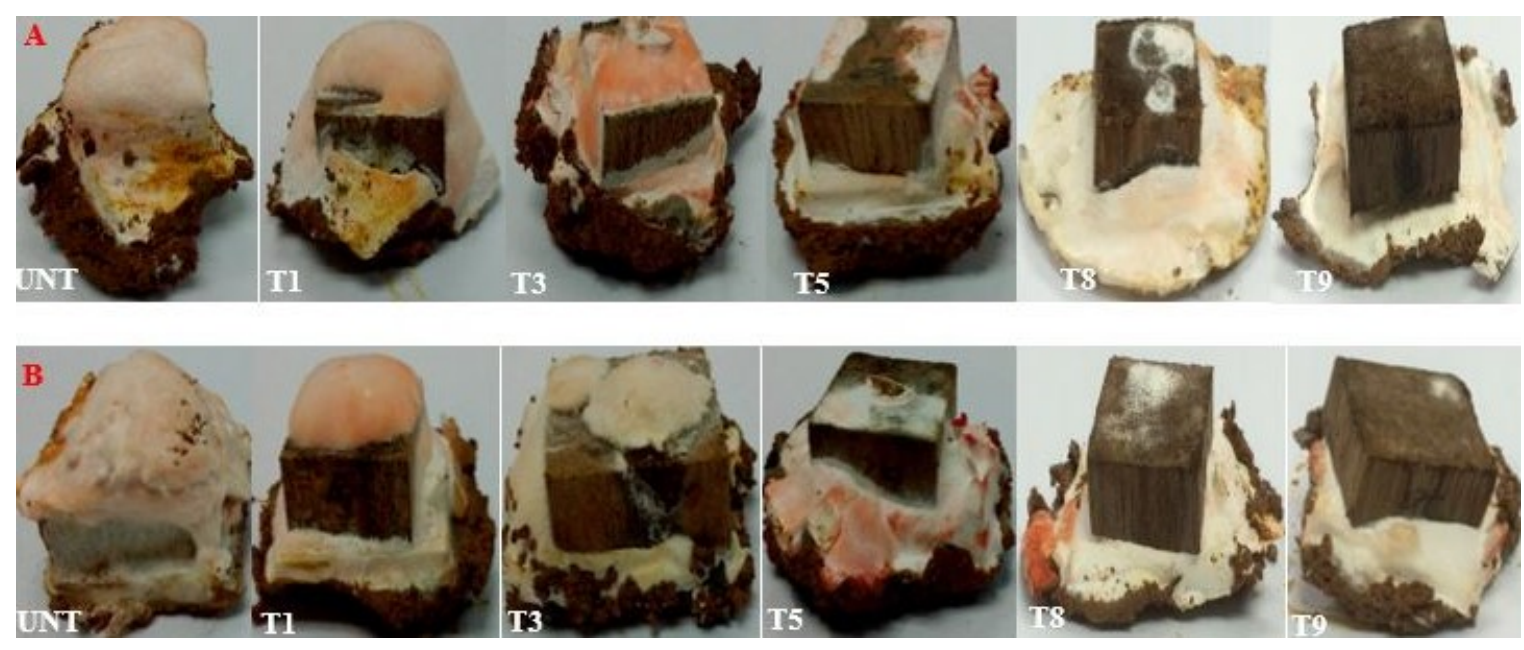

Figure 2. Visual appearance of SHS-treated and untreated light red meranti (A-upper row) and kedondong (B-lower row) samples after exposure to $P$. sanguineus at different temperatures and times; $\mathrm{UNT}=$ Untreated, $\mathrm{T} 1=172{ }^{\circ} \mathrm{C}, 180 \mathrm{~min}, \mathrm{~T} 3=180{ }^{\circ} \mathrm{C}, 240 \mathrm{~min}, \mathrm{~T} 5=200{ }^{\circ} \mathrm{C}, 180 \mathrm{~min}, \mathrm{~T} 8=22{ }^{\circ} \mathrm{C}, 240$ $\min , \mathrm{T} 9=228^{\circ} \mathrm{C}, 180 \mathrm{~min}$.

Table 4 exhibits the mean values of mass loss $\left(\mathrm{ML}_{\text {decay }}\right)$ for treated and untreated $\mathrm{LRM}$ and $\mathrm{KDD}$ due to the decay by $P$. sanguineus. The experimental results showed that the $M L_{\text {decay }}$ value ranges for treated LRM and KDD were from $1.11 \%$ to $15.99 \%$ and $1.60 \%$ to $10.55 \%$, respectively. Meanwhile, the untreated samples showed a respective $\mathrm{ML}_{\text {decay }}$ of $18.41 \%$ and $14.81 \%$ for $\mathrm{LRM}$ and KDD. A significant improvement in decay resistance was observed even when treated at the treatment condition with the 
lowest severity. The highest percentages of $\mathrm{ML}_{\text {decay }}$ in the SHS-treated LRM and KDD were recorded at approximately $15.99 \%$ and $10.55 \%$, respectively, when both of the samples were subjected to $172{ }^{\circ} \mathrm{C}$ for $180 \mathrm{~min}$ (T1). Meanwhile, the lowest percentages of $\mathrm{ML}_{\text {decay }}$ were $1.11 \%$ and $1.60 \%$, when both of the samples were exposed to $228^{\circ} \mathrm{C}$ and $180 \mathrm{~min}$ (T9).

Table 4. Mean mass loss of untreated and SHS-treated LRM and KDD samples treated at different treatment conditions as a result of fungal decay.

\begin{tabular}{ccc}
\hline \multirow{2}{*}{ Treatment } & \multicolumn{2}{c}{ Mass Loss (\%) of Fungal Decay } \\
\cline { 2 - 3 } & Light Red Meranti & Kedondong \\
\hline Untreated & $18.14 \pm 2.39^{\mathrm{f}}$ & $14.81 \pm 1.55^{\mathrm{e}}$ \\
T1 & $15.99 \pm 0.25^{\mathrm{ef}}$ & $10.55 \pm 0.33^{\mathrm{d}}$ \\
T2 & $13.80 \pm 0.78^{\mathrm{e}}$ & $8.72 \pm 1.43^{\mathrm{c}}$ \\
T3 & $10.10 \pm 3.71^{\mathrm{d}}$ & $7.61 \pm 0.36^{\mathrm{bc}}$ \\
T4 & $9.55 \pm 0.78^{\mathrm{d}}$ & $8.24 \pm 1.16^{\mathrm{c}}$ \\
T5 & $6.30 \pm 0.62^{\mathrm{c}}$ & $7.04 \pm 0.07^{\mathrm{bc}}$ \\
T6 & $4.54 \pm 0.37^{\mathrm{bc}}$ & $6.35 \pm 1.29^{\mathrm{b}}$ \\
T7 & $3.29 \pm 0.27^{\mathrm{ab}}$ & $5.91 \pm 1.07^{\mathrm{b}}$ \\
T8 & $1.69 \pm 0.25^{\mathrm{a}}$ & $2.61 \pm 0.43^{\mathrm{a}}$ \\
T9 & $1.11 \pm 0.03^{\mathrm{a}}$ & $1.60 \pm 0.33^{\mathrm{a}}$ \\
\hline
\end{tabular}

* values after \pm is standard deviation, means followed by the same letter do not differ significantly at the $p \leq 0.05$ level.

According to the ANOVA result in Table 4, the temperature and time of treatment had a significant effect on the reduction of mass for both SHS-treated samples. The reduction of mass loss was highly significant when the temperature was above $200^{\circ} \mathrm{C}(\mathrm{T} 7, \mathrm{~T} 8$, and T9). The reasons for the improvement of the treated wood against the fungal attack were mainly due to the amorphous structure of hemicellulose being degraded as a result of heat treatment, therefore, changing the wood's nature from hydrophilic to hydrophobic. As wood becomes more hydrophobic, consequently, treated wood has a lower fiber saturation point compared to untreated wood due to the decrease of the equilibrium moisture content (EMC), which prevents fungi growth by itself, and, thus, results in a better resistance against biological degradation [47].

The reduction of hemicellulose could also explain the significant improvement of decay resistance against $P$. sanguineus. As an effect of the formation degradation of hemicellulose content and other organic compounds, such as sugar and starch, during the heat treatment process, the nutrition source for fungus was eliminated from wood. In addition, the toxic substance generated during SHS treatment may possibly protect the wood from fungal decay and acetic acid that increased the acidity of wood, limiting the colonization of fungus [14,19]. Apart from that, the higher acidity of wood led by the formation of acetic acid and formic acid during thermal decomposition could also inhibit the growth of fungus [48].

\subsection{Termite Attack}

Figure 3 illustrates the visual appearance of the treated and untreated samples after 4-weeks exposure to C. curvignathus for both species. From the visual assessment, all SHS-treated and untreated specimens were attacked by termites. However, the untreated specimen displayed worse termite attacks than the treated specimens. 

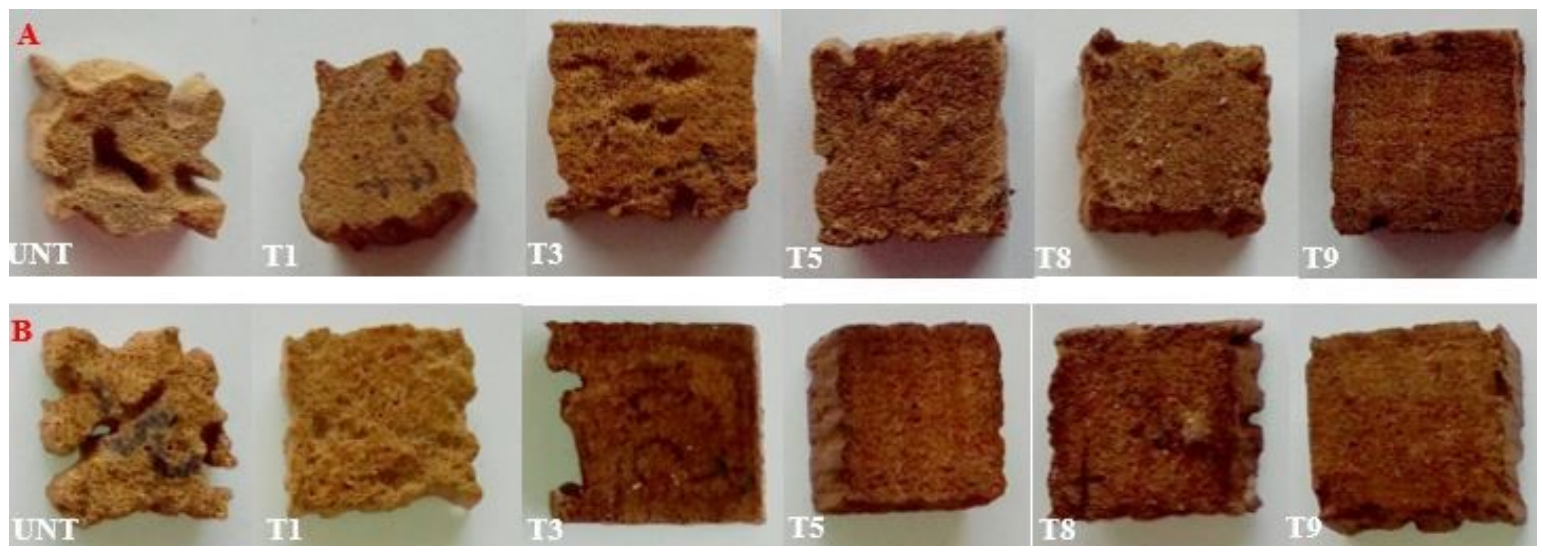

Figure 3. Visual appearance of SHS-treated and untreated light red meranti (A-upper row) and kedondong (B-lower row) samples after exposure to C. curvignathus at different temperatures and times; $\mathrm{UNT}=$ Untreated, $\mathrm{T} 1=172{ }^{\circ} \mathrm{C}, 180 \mathrm{~min}, \mathrm{~T} 3=180^{\circ} \mathrm{C}, 240 \mathrm{~min}, \mathrm{~T} 5=20{ }^{\circ} \mathrm{C}, 180 \mathrm{~min}, \mathrm{~T} 8=220^{\circ} \mathrm{C}$, $240 \mathrm{~min}, \mathrm{~T} 9=228^{\circ} \mathrm{C}, 180 \mathrm{~min}$.

Table 5 depicts the mean values of the mass loss $\left(\mathrm{ML}_{\text {termites }}\right)$ of the specimens due to the $C$. curvignathus attack. From the experimental results, inconsistent results were observed in the $\mathrm{ML}_{\text {termites }}$ of SHS-treated and untreated LRM and KDD samples. As shown, the untreated specimen for both samples was most attacked by termites with the maximum $\mathrm{ML}_{\text {termites }}$ values of $43.98 \%$ and $59.91 \%$, respectively, compared to the treated specimens. The higher $\mathrm{ML}_{\text {termites }}$ for SHS-treated LRM was recorded at a treatment condition of $220^{\circ} \mathrm{C}$ for $120 \mathrm{~min}$ (T7) and for KDD, at $172{ }^{\circ} \mathrm{C}$ for $180 \mathrm{~min}$ (T1). Meanwhile, the minimum $\mathrm{ML}_{\text {termites }}$ for $\mathrm{LRM}$ and $\mathrm{KDD}$ were observed when the samples were subjected to $180{ }^{\circ} \mathrm{C}$ for $120 \mathrm{~min}$ (T2) and $200{ }^{\circ} \mathrm{C}$ for $265 \mathrm{~min}$ (T6), which accounted for $17.82 \%$ and $13.53 \%$, respectively. Unsal et al. [49] reported that thermally compressed Scotch pine solid panels revealed better termite resistance compared to that of the control panel. However, the degradation pattern was inconsistent as pressing temperatures did not exert significant influence on the mass loss by termites.

Table 5. Mean mass loss for termite attacks of SHS-treated LRM and KDD samples in different treatment conditions.

\begin{tabular}{ccc}
\hline \multirow{2}{*}{ Treatment } & \multicolumn{2}{c}{ Mass Loss (\%) of Termite Resistance } \\
\cline { 2 - 3 } & Light Red Meranti & Kedondong \\
\hline Untreated & $43.98 \pm 12.51^{\mathrm{b}}$ & $59.91 \pm 7.74^{\mathrm{c}}$ \\
T1 & $21.76 \pm 9.08^{\mathrm{a}}$ & $35.79 \pm 18.58^{\mathrm{b}}$ \\
T2 & $17.82 \pm 11.06^{\mathrm{a}}$ & $21.39 \pm 12.66^{\mathrm{a}}$ \\
T3 & $29.06 \pm 13.25^{\mathrm{ab}}$ & $23.35 \pm 9.20^{\mathrm{ab}}$ \\
T4 & $28.90 \pm 15.76^{\mathrm{ab}}$ & $22.98 \pm 12.45^{\mathrm{ab}}$ \\
T5 & $26.64 \pm 7.89^{\mathrm{a}}$ & $23.77 \pm 6.40^{\mathrm{ab}}$ \\
T6 & $22.97 \pm 7.24^{\mathrm{a}}$ & $13.53 \pm 3.45^{\mathrm{a}}$ \\
T7 & $32.94 \pm 17.84^{\mathrm{ab}}$ & $14.99 \pm 3.72^{\mathrm{a}}$ \\
T8 & $32.29 \pm 14.60^{\mathrm{ab}}$ & $17.27 \pm 2.49^{\mathrm{a}}$ \\
T9 & $30.33 \pm 3.01^{\mathrm{ab}}$ & $16.39 \pm 5.66^{\mathrm{a}}$ \\
\hline
\end{tabular}

* values after \pm is standard deviation, means followed by the same letter do not differ significantly at the $p \leq 0.05$ level.

\subsection{Correlation between Weight Loss and Equilibrium Moisture Content of Wood Speciemens}

Figure 4 illustrates the relationship between weight loss (WL) after the SHS treatment and equilibrium moisture content (EMC) for both LRM and KDD. A strong relationship was observed between $W L$ and EMC for both LRM and KDD $\left(R^{2}=0.7427\right.$ and 0.7359 , respectively $)$. From Figure 4, one can see that as the WL increased, the EMC of the treated wood decreased. The weight loss of the 
heat-treated wood was mainly attributed to the degradation of wood polymers-particularly, the most thermally labile hemicellulose [50]. As a result, the hygroscopicity of the wood was reduced after SHS treatment. Several studies have shown that the key reason for the improvement in fungal decay resistance is the resulted hydrophobic character of the heat-treated wood [47,51]. The main function of moisture in wood is to facilitate the transportation of diffusible agents from fungi into the wood cell wall [52]. By excluding or reducing the moisture from wood through thermal treatment, the ingress of fungi into the cell wall was obstructed.

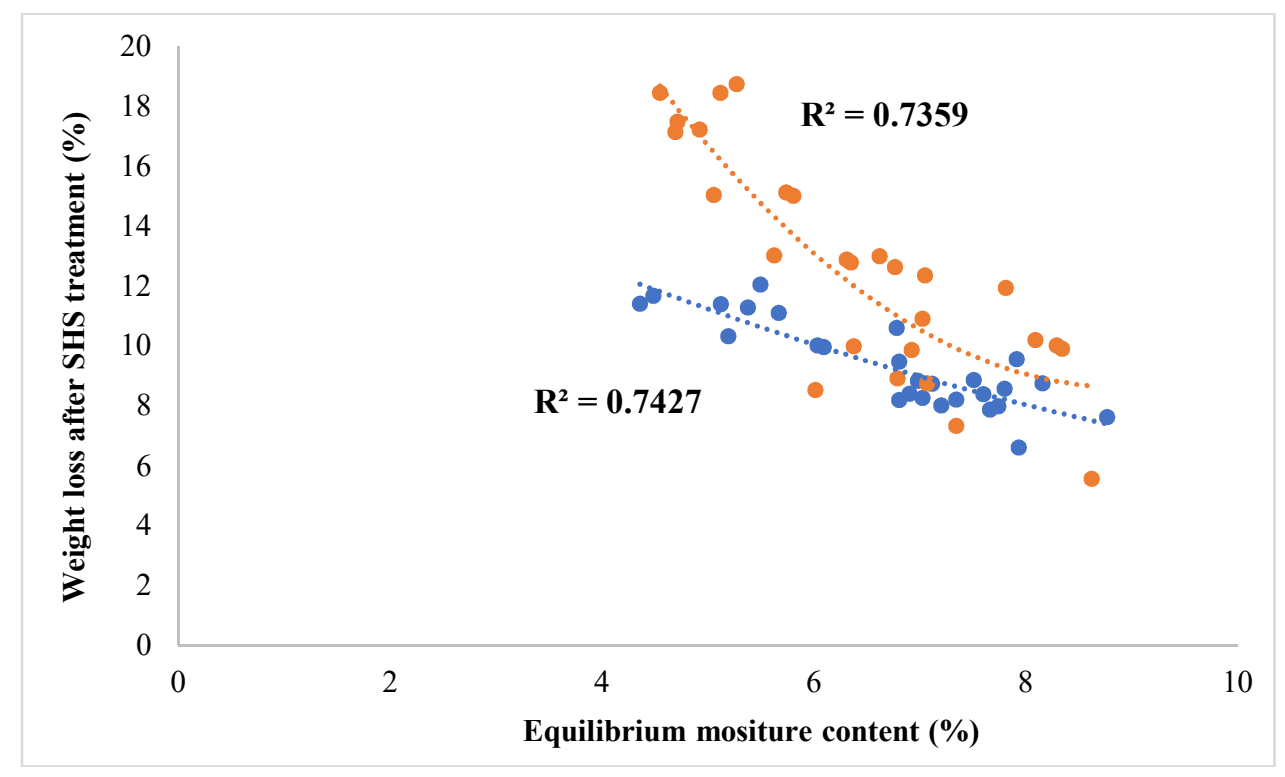

Figure 4. Correlation between weight loss after SHS treatment and equilibrium moisture content of superheated steam-treated light red meranti (LRM) and kedondong (KDD) wood.

\subsection{Correlation between Thermal-Induced Weight Loss of Wood Speciemens and Mass Loss}

The weight loss (WL) of the wood samples, caused by thermal treatment, could be a good indicator for predicting the mass loss caused by fungus and termites. A previous study by Rasdianah et al. [27] revealed that the weight loss of superheated steam-treated LRM and KDD wood ranged from $8.18 \%$ to $11.48 \%$ and $8.19 \%$ to $18.55 \%$, respectively. The relationship between WL after SHS treatment, with $\mathrm{ML}_{\text {decay }}$ and $\mathrm{ML}_{\text {termites, }}$, are shown in Figure 5.

The WL was well correlated to the $M L_{\text {decay }}$ caused by fungal decay, as strong relationships were observed between $W L$ and $M L_{\text {decay }}$ for both the $L R M$ and $K D D$ wood $\left(R^{2}=0.7903\right.$ and 0.8902 , respectively). On the contrary, poor relationships between $\mathrm{WL}$ and $\mathrm{ML}_{\text {termites }}$ were observed for both LRM and KDD wood. A previous study by Hakkou et al. [53] revealed that the decay durability of wood against Coriolus versicolor is strongly correlated to the weight loss induced by thermal degradation. The more mass loss in the heating process, the more durable the heat-treated wood than the untreated wood. Similarly, Rowell et al. [54] found that the higher the WL due to thermal treatment, the higher the decay resistance of the wood. Nevertheless, conflicting results on the effectiveness of thermal treatment on the termite resistance of wood has been reported by several studies. In a review done by Lee et al. [11], the authors stated that contradictory results are often observed in heat-treated wood samples against termite attacks. A negative consequence after SHS treatment is that the treated wood becomes more brittle as the treatment time increases [55,56], has a tendency to crack [54], and can easily be eaten by termites because of the degradation of the lignocellulose compound [24]. The possible reason for the higher reduction of mass loss by SHS-treated samples against termite attacks was from the chemical modification that changed the termiticide chemical in wood (taxifolin) into an attractive compound for termites during SHS treatment $[57,58]$. 


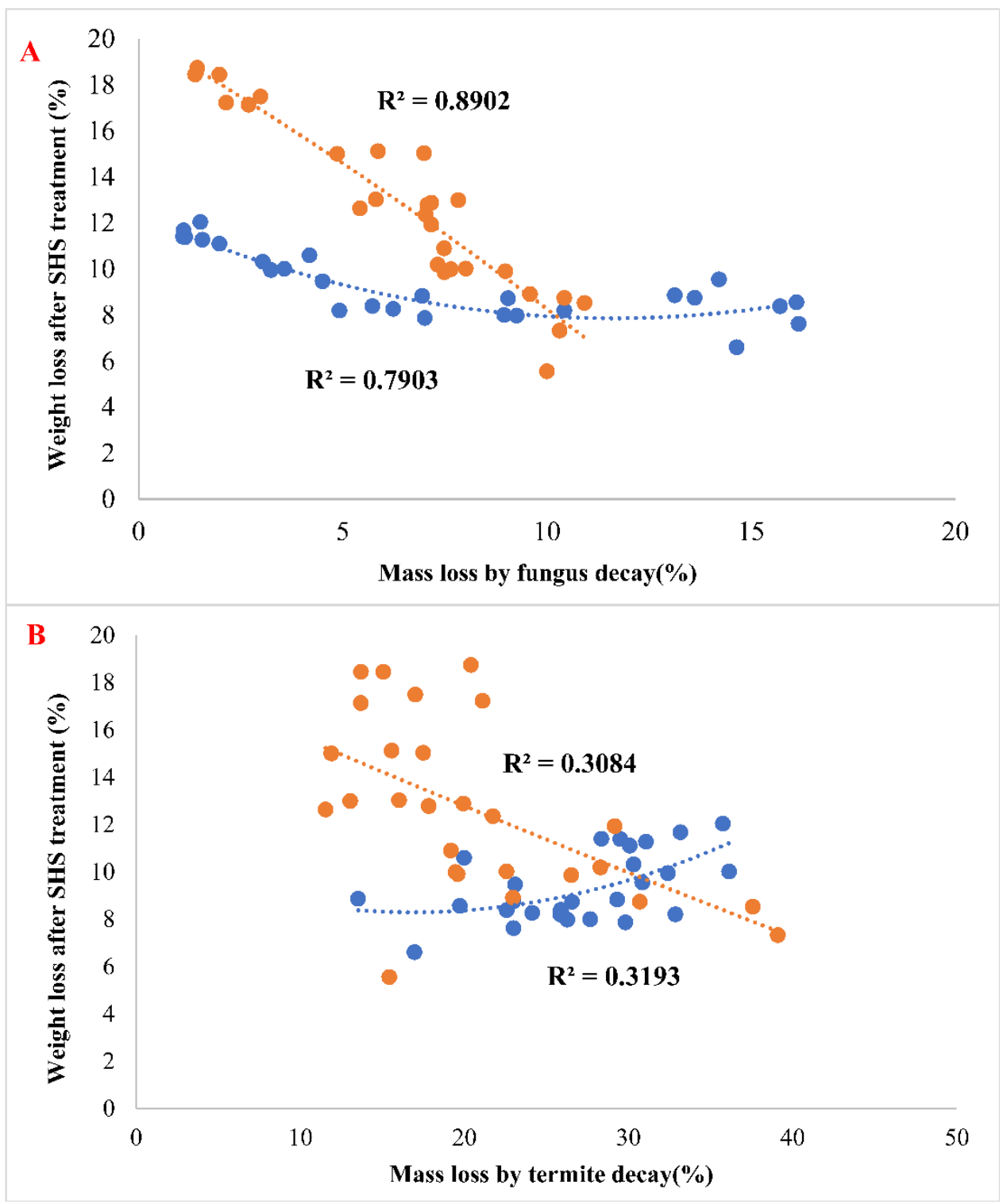

Figure 5. Correlation between weight loss caused by heat treatment with (A) fungal decay and (B) termite attack of superheated steam-treated light red meranti (LRM) and kedondong (KDD) wood.

\section{Conclusions}

The chemical composition of light red meranti and kedondong wood was significantly altered after being subjected to superheated steam treatment. Hemicelluloses, cellulose, and lignin of both woods were significantly reduced by the treatment when treated at temperatures higher than $200^{\circ} \mathrm{C}$. Between the two variables, the treatment temperature was more significant than time in affecting the chemical constituents. As a result, a significant improvement in the resistance of LRM and KDG against $P$. sanguineus was attained. The treatment at $228^{\circ} \mathrm{C}$ for $180 \mathrm{~min}$ (T9) imparted the highest resistance against fungal decay to both LRM and KDG wood. The SHS-treated wood also showed an increment in resistance against $C$. curvignathus. However, an inconsistent pattern was observed, as the highest treatment temperature and longest treatment time did not necessarily endow the treated wood with the highest resistance against termites.

Author Contributions: Conceptualization, Z.A. and P.B.; Methodology, E.S.B. and H.A.; Formal Analysis, S.H.L. and H.A.; Investigation, R.D., P.S.K., and Q.N.S.; Data Curation, R.D., P.S.K., and Q.N.S.; Writing-Original Draft Preparation, R.D. and S.H.L.; Writing-Review \& Editing, Z.A. and S.H.L.; Supervision, Z.A., E.S.B., and H.A.; 
Project Administration, Z.A. and S.H.L.; Funding Acquisition, E.S.B.; P.B. All authors have read and agreed to the published version of the manuscript.

Funding: This work is supported by Higher Institutions' Centre of Excellence (HICoE) from the Ministry of Education, Malaysia, and research project Geran Inisiatif Putra Siswazah with project number of GP-IPS 9519600.

Conflicts of Interest: The authors declare no conflict of interest.

\section{References}

1. Thybring, E.E. Water relations in untreated and modified wood under brown-rot and white-rot decay. Int. Biodeterior. Biodegrad. 2017, 118, 134-142. [CrossRef]

2. Mahapatro, G.K.; Chatterjee, D. Termites as structural pest: Status in Indian Scenario. Proc. Natl. Acad. Sci. India B 2018, 88, 977-994. [CrossRef]

3. Rust, M.K.; Su, N.Y. Managing social insects of urban importance. Annu. Rev. Entomol. 2012, 57, $355-375$. [CrossRef] [PubMed]

4. $\quad$ Ngee, P.S.; Yoshimura, T.; Lee, C.Y. Foraging populations and control strategies of subterranean termites in the urban environment, with special reference to baiting. Jpn. J. Appl. Entomol. Zool. 2004, 15, 197-215.

5. Kleindienst, Q.; Besserer, A.; Antoine, M.; Perrin, C.; Bocquet, J.; Bleron, L. Predicting the beech wood decay and strength loss in-ground. Int. Biodeterior. Biodegrad. 2017, 123, 96-105. [CrossRef]

6. Morrell, J.J. Protection of Wood Based Materials. In Handbook of Environmental Degradation of Materials; Kutz, M., Ed.; William Andrew: Norwich, NY, USA, 2005; pp. 299-317.

7. Takemoto, S.; Hwang, W.J.; Takeuchi, M.; Itoh, T.; Imamura, Y. Anatomical characterization of decayed wood in standing light red meranti and identification of the fungi isolated from the decayed area. J. Wood. Sci. 2008, 54, 233-241.

8. Bami, M.L.; Kamarudin, M.S.; Saad, C.R.; Arshad, A.; Ebrahimi, M. Effects of canarium fruit (Canarium odontophyllum) oil as a dietary lipid source for juvenile mahseer (Tor tambroides) performance. Aquac. Rep. 2017, 6, 8-20. [CrossRef]

9. Jackson, W.F. Durability of Malayan Timbers; Malayan Forest Service Trade Leaflet No. 28; Government Printing Department: Kuala Lumpur, Malaysia, 1965.

10. Gascon-Garrido, P.; Oliver-Villanueva, J.V.; Ibiza-Palacios, M.S.; Militz, H.; Mai, C.; Adamopoulos, S. Resistance of wood modified with different technologies against Mediterranean termites (Reticulitermes spp.). Int. Biodeterior. Biodegrad. 2013, 82, 13-16. [CrossRef]

11. Lee, S.H.; Ashaari, Z.; Lum, W.C.; Juliana, A.H.; Ang, A.F.; Tan, L.P.; Chin, K.L.; Paridah, M.T. Thermal treatment of wood using vegetable oils: A review. Constr. Build. Mater. 2018, 181, 408-419. [CrossRef]

12. Lee, S.H.; Ashaari, Z.; Lum, W.C.; Ang, A.F.; Juliana, A.H.; Halis, R. Chemical, physico-mechanical properties and biological durability of rubberwood particleboards after post heat-treatment in palm oil. Holzforschung 2018, 72, 159-167. [CrossRef]

13. Lee, S.H.; Zaidon, A.; Ang, A.F.; Juliana, A.H.; Lum, W.C.; Dahali, R.; Halis, R. Effects of two-step post heat-treatment in palm oil on the properties of oil palm trunk particleboard. Ind. Crop. Prod. 2018, 116, 249-258. [CrossRef]

14. Boonstra, M.; Van Acker, J.; Kegel, E.; Stevens, M. Optimisation of a two-stage heat treatment process. Durability aspects. Wood Sci. Technol. 2007, 41, 31-57.

15. Chaouch, M.; Dumarcay, S.; Petrissans, A.; Petrissans, M.; Gerardin, P. Effect of heat treatment intensity on some conferred properties of different European softwood and hardwood species. Wood Sci. Technol. 2013, $47,663-673$.

16. Dubey, M.K.; Pang, S.; Chauhan, S.; Walker, J. Dimensional stability, fungal resistance and mechanical properties of radiata pine after combined thermomechanical compression and oil heat-treatment. Holzforschung 2016, 70, 793-800. [CrossRef]

17. Gao, J.; Kim, J.S.; Terziev, N.; Daniel, G. Decay resistance of softwoods and hardwoods thermally modified by the Thermovouto type thermo-vacuum process to brown rot and white rot fungi. Holzforschung 2016, 70 , 877-884.

18. Gao, J.; Kim, J.S.; Terziev, N.; Cuccui, I.; Daniel, G. Effect of thermal modification on the durability and decay patterns of hardwoods and softwoods exposed to soft rot fungi. Int. Biodeterior. Biodegrad. 2018, 127, 35-45. 
19. Mburu, F.; Dumarcay, S.; Huber, F.; Petrissans, M.; Gerardin, P. Evaluation of thermally modified Grevillea robusta heartwood as an alternative to shortage of wood resource in Kenya: Characterisation of physicochemical properties and improvement of bio-resistance. Bioresour. Technol. 2007, 98, 3478-3486. [CrossRef]

20. Lyon, F.; Thevenon, M.; Hwang, W.; Imamura, Y.; Gril, J.; Pizzi, A. Effect of an oil heat treatment on the leachability and biological resistance of boric acid impregnated wood. Ann. For. Sci. 2007, 64, 673-678. [CrossRef]

21. Manola, R.D.; Garcia, C.M. Termite resistance of thermally-modified Dendrocalamus asper (Schultes f.) Backer ex Heyne. Insects 2012, 3, 390-395. [CrossRef]

22. Oliver-Villanueva, J.; Gascón-Garrido, P.; Ibiza-Palacios, M.S. Evaluation of thermally-treated wood of beech (Fagus sylvatica L.) and ash (Fraxinus excelsior L.) against Mediterranean termites (Reticulitermes spp.). Eur. J. Wood Wood Prod. 2013, 71, 391-393. [CrossRef]

23. Shi, J.L.; Kocaefe, D.; Amburgey, T.; Zhang, J. A comparative study on brown-rot fungus decay and subterranean termite resistance of thermally-modified and ACQ-C-treated wood. Holz. Roh. Werkst. 2007, 65, 353-358. [CrossRef]

24. Surini, T.; Charrier, F.; Malvestio, J. Physical properties and termite durability of maritime pine (Pinus pinaster Ait), heat-treated under vacuum pressure. Wood Sci. Technol. 2012, 46, 487-501.

25. Gradeci, K.; Labonnote, N.; Time, B.; Kohler, J. Mould growth criteria and design avoidance approaches in wood-based materials-A systematic review. Constr. Build. Mater. 2017, 150, 77-88. [CrossRef]

26. Ahmed, S.A.; Sehlstedt-Persson, M.; Moren, T. Mould susceptibility of Scots pine (Pinus sylvestris L.) sapwood: Impact of drying, thermal modification, and copper-based preservative. Int. Biodeterior. Biodegrad. 2013, 85, 284-288. [CrossRef]

27. Rasdianah, D.; Ashaari, Z.; Hidayah, A.; Lee, S.H. Effects of superheated steam treatment on the physical and mechanical properties of light red meranti and kedondong wood. J. Trop. For. Sci. 2018, 30, 384-392.

28. Tang, Z.; Cenkowski, S.; Izydorczyk, M. Thin-layer drying of spent grains in superheated steam. J. Food Eng. 2005, 67, 457-465.

29. Head, D.; Cenkowski, S.; Arntfield, S.; Henderson, K. Storage stability of oat groats processed commercially and with superheated steam. LWT Food Sci. Technol. 2011, 44, 261-268. [CrossRef]

30. Mahmud, N.A.N.; Baharuddin, A.S.; Bahrin, E.K.; Sulaiman, A.; Naim, M.N.; Zakaria, R.; Hassan, M.A.; Nishida, H.; Shirai, Y. Enzymatic saccharification of oil palm mesocarp fiber (OPMF) treated with superheated steam. BioResources 2013, 8, 1320-1331.

31. Umar, I.S.S.; Zaidon, A.; Lee, S.H.; Rasmina, H. Oil-heat treatment of rubberwood for optimum changes in chemical constituents and decay resistance. J. Trop. For. Sci. 2016, 28, 88-96.

32. TAPPI Standard, T 257 cm-02. Sampling and Preparing Wood for Chemical Analysis; TAPPI: Atlanta, GA, USA, 2002.

33. TAPPI Standard, T 204 cm-97. Wood Extractives in Ethanol-Benzene Mixture; TAPPI: Atlanta, GA, USA, 1997.

34. TAPPI Standard, T 212 om-93. One Percent Sodium Hydroxide Solubility of Wood and Pulp; TAPPI: Atlanta, GA, USA, 1993.

35. TAPPI Standard, T 222 om-02. Acid-Insoluble Lignin in Wood and Pulp; TAPPI: Atlanta, GA, USA, 2002.

36. ASTM Standard D 1413-76. Reapproved. Standard Test Method for Wood Preservatives by Laboratory Soil-Block Cultures; ASTM International: West Conshohocken, PA, USA, 2009.

37. Roszaini, K.; Hale, M.D.; Salmiah, U. In-vitro decay resistance of 12 Malaysian broadleaf hardwood trees as a function of wood density and extractives compounds. J. Trop. For. Sci. 2016, 28, 533-540.

38. Scheffer, T.C. Biological observations of significance for improved preservative treatment. Holzforschung 1964, 18, 88-94. [CrossRef]

39. Bakar, E.S.; Hao, J.; Ashaari, Z. Durability of phenolic-resin-treated oil palm wood against subterranean termites a white-rot fungus. Int. Biodeterior. Biodegrad. 2013, 85, 126-130. [CrossRef]

40. ASTM Standard D 3345-08. Standard Test Method for Laboratory Evaluation of Wood and other Cellulosic Materials for Resistance to Termites; ASTM International: West Conshohocken, PA, USA, 2008.

41. Candelier, K.; Thevenon, M.F.; Petrissans, A.; Dumarcay, S.; Gerardin, P.; Petrissans, M. Control of wood thermal treatment and its effects on decay resistance: A review. Ann. For. Sci. 2016, 73, 571-583. [CrossRef]

42. Zaman, A.; Alen, R.; Kotilainen, R. Thermal behavior of Scots pine (Pinus sylvestris) and silver birch (Betula pendula) at $200-230{ }^{\circ}$ C. Wood Fiber Sci. 2000, 32, 138-143. 
43. Esteves, B.; Videira, R.; Pereira, H. Chemistry and ecotoxicity of heat treated pine wood extractives. Wood Sci. Technol. 2011, 45, 661-676. [CrossRef]

44. Esteves, B.; Graca, J.; Pereira, H. Extractive composition and summative chemical analysis of thermally treated eucalypt wood. Holzforschung 2008, 62, 344-351. [CrossRef]

45. Tjeerdsma, B.; Boonstra, M.; Militz, H. Thermal Modification of Non-Durable Wood Species. Part 2. Improved Wood Properties of Thermally Treated Wood; Document no. IRG/WP 98-40124; International Research Group on Wood Protection: Stockholm, Sweden, 1998.

46. Kishimoto, T.; Ueki, A.; Sano, Y. Delignification Mechanism during High-boiling solvent pulping part 3. structural changes in lignin analyzed by 13C-NMR spectroscopy. Holzforschung 2003, 57, 602-610. [CrossRef]

47. Weiland, J.; Guyonnet, R. Study of chemical modifications and fungi degradation of thermally modified wood using DRIFT spectroscopy. Holz. Roh. Werkst. 2003, 61, 216-220. [CrossRef]

48. Wang, Y.; Zhang, Z.; Fan, H.; Wang, J. Wood carbonization as a protective treatment on resistance to wood destroying fungi. Int. Biodeterior. Biodegrad. 2018, 129, 42-49. [CrossRef]

49. Unsal, O.; Kartal, S.M.; Candan, Z.; Arango, R.A.; Clasuen, C.A.; Green, F. Decay and termite resistance, water absorption and swelling of thermally compressed wood panels. Int. Biodeterior. Biodegrad. 2009, 63, 548-552. [CrossRef]

50. Dos Santos, D.V.B.; de Moura, L.F.; Brito, J.O. Effect of heat treatment on color, weight loss, specific gravity and equilibrium moisture content of two low market valued tropical woods. Wood Res. 2014, 59, 253-264.

51. Li, T.; Cheng, D.; Avramidis, S.; Walinder, M.E.P.; Zhou, D. Response of hygroscopicity to heat treatment and its relation to durability of thermally modified wood. Constr. Build. Mater. 2017, 144, 671-676. [CrossRef]

52. Thybring, E.E. The decay resistance of modified wood influenced by moiture exclusion and swelling reduction. Int. Biodeterior. Biodegrad. 2013, 82, 87-95. [CrossRef]

53. Hakkou, M.; Petrissans, M.; Gerardin, P.; Zoulalian, A. Investigation of the reasons for fungal durability of heat-treated beech wood. Polym. Degrad. Stab. 2006, 91, 393-397. [CrossRef]

54. Rowell, R.M.; Ibach, R.E.; James, M. Understanding decay resistance, dimensional stability and strength changes in heat-treated and acetylated wood. Wood Mater. Sci. Eng. 2009, 4, 14-22. [CrossRef]

55. Yao, J.; Taylor, F. Effect of high-temperature drying on the strength of southern pine dimension lumber. Forest Prod. J. 1979, 29, 49-51.

56. Edlund, M.L.; Jermer, J. Durability of Some Alternatives to Preservative Treated Wood; Document NO. IRG/WP, 04-30353; International Research Group on Wood Protection: Stockholm, Sweden, 2004.

57. Doi, S.; Aoyama, M.; Yamauchi, S.; Kurimoto, Y. Changes of decay and termite durabilities of Japanese larch (Larix leptolepis) wood due to high temperature kiln drying process. J. Wood Sci. 2005, 51, 526-530. [CrossRef]

58. Doi, S.; Kurimoto, Y.; Ohmura, W.; Ohara, S.; Aoyama, M.; Yoshimura, T. Effects of heat treatments on the feeding behaviour of two subterranean termites. Holzforschung 1999, 53, 225-229. [CrossRef] 